\title{
MODEL PEMBELAJARAN KOLABORATIF DAN KREATIF UNTUK MENGHADAPI TUNTUTAN ERA REVOLUSI INDUSTRI 4.0
}

\author{
Koko Adya Winata \\ UIN Sunan Gunung Djati Bandung \\ E-mail: adyawinata@gmail.com
}

\begin{abstract}
This paper examines how learning models should be applied in schools to respond to the demands of the era of the industrial revolution 4.0 which has become a necessity. The industrial revolution 4.0 is an era that shows the rapid development of technology and has caused many jobs in the past to be distorted. The role of humans is taken over step by step by automatic machines, as a result the number of unemployment is increasing. In order to avoid the negative impact of the industrial revolution 4.0, educational institutions must be able to answer these challenges by selecting and applying learning models in schools that provide the skills or skills needed. The demand for skills that can answer the challenges of the 4.0 revolution era, must be prepared through a directed and comprehensive learning plan. This means that the learning process does not only think and move towards the academic dimension. In the learning process, often students are only prepared to have intellectual intelligence and very little learning gives equal opportunities to students to hone other intelligence. At the same time the learning method is more dominated by the authority of the teacher which is very central and rigid, while the students are positioned as objects that must accept what is presented by the teacher. As a result, students do not have the ability to develop their creativity and potential. Learning models that can answer the challenges of the revolution era 4.0 are collaborative and creative learning models. Through collaborative and creative learning, students are directed to be able to develop their potential and hone their creative thinking skills. The collaborative and creative learning model makes it easy for students to learn and work together and learn to solve problems together. Creative thinking to solve existing problems is a learning process needed to answer the challenges of the industrial revolution 4.0.
\end{abstract}

Keywords: Learning Model, Collaborative, Creative, Industrial Revolution 4.0

\section{PENDAHULUAN}

Lembaga pendidikan sebagai lembaga yang bertanggung jawab secara langsung dalam mencetak lulusan yang berkualitas. Hal itu akan mendapat tantangan yang cukup berat, karena belum semua sumber daya manusia siap menghadapi tantangan tersebut. Tidak semua guru memiliki pemahaman dan kemampuan dalam menyiapkan siswa yang terampil dan handal dalam menghadapi tuntutan era revolusi 4.0. Beberapa penelitian masih menunjukkan lemahnya kemampuan berfikir siswa dimana hal ini menjadi dasar yang penting bagi siswa untuk mengembangkan skill atau keterampilan yang dibutuhkan (Qiqi Yuliati Z, 2019). Untuk menghadapi tuntutan ini, guru harus mampu membangun dan menerapkan kondisi proses pembelajaran yang sesuai dengan kebutuhan. Guru mempunyai peran yang sangat penting dalam proses pembelajaran berlangsung mulai dari merancang pembelajaran, memilih model dan metode pembelajaran. Pigur dan kepemimpinan guru mempunyai andil yang besar terhadap 
sukses tidaknya pembelajaran. Oleh karena itu, guru harus memiliki pengetahuan yang memadai, pengalaman dan kompetensi yang baik agar tujuan pembelajaran dapat tercapai dengan baik.

Model pembelajaran yang diterapkan guru harus dapat mengarahkan peserta didik untuk memiliki kemampuan memahami, memprediksi dan berpikir kreatif dan kritis terhadap segala informasi sehingga peserta didik memiliki keterampilan yang dibutuhkan dalam menghadapi era revolusi 4.0. Menurut Joice\& Weil (dalam Isjoni, 2013) bahwa model pembelajaran adalah suatu pola atau rencana yang sudah direncanakan sedemikian rupa dan digunakan untuk menyusun kurikulum, mengatur materi pelajaran, dan memberi petunjuk kepada pengajar di kelasnya. Model pembelajaran sangat erat kaitannya dengan gaya belajar peserta didik dan gaya mengajar guru. Usaha dan kerja keras guru di era revolusi 4.0 dalam membelajarkan peserta didik merupakan bagian yang sangat penting dalam mencapai keberhasilan tujuan pembelajaran yang menghasilkan skill atau keterampilan peserta didik. Revolusi Industri 4.0 secara fundamental telah mengakibatkan berubahnya cara manusia berpikir, hidup, dan berhubungan satu dengan yang lain.

Era ini telah mendistrupsi aktivitas manusia dalam berbagai bidang, tidak hanya dalam bidang teknologi saja, namun juga bidang yang lain seperti ekonomi, sosial, dan politik. Pada awalnya fenomena distrupsi berlaku hanya di bidang ekonomi. Namun Fenomena distrupsi telah meluas dalam bidang lainnya seperti pendidikan, pemerintahan, budaya, politik, dan hukum. Revolusi Industri 4.0 telah menerapkan konsep automatisasi yang dilakukan oleh mesin dan tidak lagi memerlukan keterlibatan tenaga manusia. Automatisasi telah sangat massif dan tidak memerlukan tenaga manusia dalam pengaplikasiannya. Dimana hal tersebut merupakan hal vital yang dibutuhkan oleh para pelaku industri demi efisiensi waktu, tenaga kerja, dan biaya. Penerapan Revolusi Industri 4.0 di pabrik-pabrik dikenal dengan istilah Smart Factory. Revolusi industry 4.0 telah mengubah paradigma bisnis dari penekanan owning menjadi sharing (kolaborasi). Contoh nyata dalam kehidupan dapat dilihat pada perpindahan bisnis retail (toko fisik) ke dalam e commerce yang menawarkan kemudahan dalam berbelanja. Merebaknya layanan berkendara taksi dan ojeg online yang kemudian mengancam eksistensi bisnis taksi dan ojeg konvensional. Pada bidang politik misalnya, gerakan-gerakan politis untuk mengumpulkan masa melalui konsentrasi masa telah digantikan dengan gerakan berbasis media sosial. Pengerahan massa diruang public bergeser bentuk dan caranya dengan pengerahan massa di media social. Bidang pemerintahan pun kini juga ditantang untuk melaksanakan birokrasi secara efektif dan efisien berbasis e governance (Banu Prasetyo, jurnal). Kriteria yang signifikan di era revolusi 4.0 adalah terdapat banyak inovasi baru, diantaranya Internet of Things (IoT), Big Data, percetakan 
3D, Artifical Intelligence (AI), kendaraan tanpa pengemudi, rekayasa genetika, robot dan mesin pintar.

Salah satu hal terbesar didalam Revolusi Industri 4.0 adalah Internet of Things. Fenomena tersebut harus direspon oleh lembaga pendidikan dengan menerapkan model pembelajaran yang dapat menjawab tantangan itu. Kemampuan berfikir kreatif dan kritis harus disiapkan oleh berbagai pihak yang terkait dengan lembaga pendidikan agar peserta didik mampu menghadapi tuntutan era revolusi industry 4.0. Oleh sebab itu, guru harus memiliki kompetensi yang mumpuni yang dapat mengarahkan dan membimbing peserta didik agar memiliki keterampilan yang memadai. Model pembelajaran yang diterapkan dalam proses pembelajaran harus mengarahkan peserta didik memiliki keterampilan dalam bekerja sama, berkreasi dan berkomunikasi. Pembelajaran harus menekankan pentingnya pengembangan belajar secara bermakna dan pemecahan masalah secara intelektual serta pengembangan aspek social. Model pembelajaran yang dilakukan guru harus mendorong kemampuan peserta didik terhadap mencipta sesuatu yang baru, gagasan baru yang dapat diterapkan untuk memecahkan masalah yang ada. Menurut hemat penulis, model pembelajaran kolaboratif dan kreatif diyakini dapat menjadi solusi untuk menghadapi tantangan era revolusi industry 4.0 .

\section{METODE PENELITIAN}

Metode penelitian yang dipergunakan dalam penelitian ini adalah metode kualitatif. Pendekatan penelitian kualitatif sering disebut sebagai metode penelitian naturalistik karena penelitiannya dilakukan pada kondisi yang alamiah (natural setting). Dalam penelitian kualitatif unsur kecermatan dan langkah yang sistematis memegang peranan sangat penting. Dengan menggunakan pendekatan kualitatif diharapkan peneliti dapat lebih leluasa dalam memahami, mengamati dan melakukan penelaahan lebih akurat berkenaan dengen model pembelajaran kolaboratif dan kreatif untuk menghadapi tuntutan era revolusi industri 4.0. Tuntutan akan sumber daya manusia yang handal berkenaan dengan era digitalisasi mengharuskan proses pembelajaran menekankan kepada pengembangan potensi peserta didik melalui model pembelajaran kolaboratif dan kreatif. Model pembelajaran tidak hanya menekankan kepada transfer of knowlage dimana guru sangat dominan dalam proses pembelajaran namun pembelajaran yang menghasilkan peserta didik yang kreatif dan kritis dalam memecahkan permasalahan yang dihadapi. Peneliti dapat dengan leluasa memahami dan menganalisa melalui kajian yang kritis dan sistematis tentang pentingnya model pembelajaran yang mampu menjawab tantangan era revolusi industri 4.0 . 


\section{HASIL DAN PEMBAHASAN}

\section{Era Revolusi Industri 4.0}

Istilah revolusi Industri 4.0 secara resmi lahir di Jerman tepatnya saat diadakan Hannover Fair pada tahun 2011 (Kagermann, 2013). Negara Jerman memiliki kepentingan yang besar terkait hal ini karena Industri 4.0 menjadi bagian dari kebijakan rencana pembangunan negaranya yang disebut High-Tech Strategy 2020. Kebijakan tersebut bertujuan untuk mempertahankan Jerman agar selalu menjadi yang terdepan dalam dunia manufaktur (Heng, 2013). Menurut Kagermann dkk (2013) bahwa Industri 4.0 adalah integrasi dari Cyber Physical System (CPS) dan Internet of Things and Services (IoT dan IoS) ke dalam proses industri meliputi manufaktur dan logistik serta proses lainnya. CPS adalah teknologi untuk menggabungkan antara dunia nyata dengan dunia maya. Industri 4.0 dapat diartikan sebagai era industri di mana seluruh entitas yang ada di dalamnya dapat saling berkomunikasi secara real time kapan saja dengan berlandaskan pemanfaatan teknologi internet dan CPS. Integrasi teknologi ini dimaksudkan untuk mencapai kreasi nilai baru ataupun optimasi nilai yang sudah ada dari setiap proses di industry dan di bidang lain yang merupakan ciri dari era revolusi industry 4.0..

Untuk menghadapi revolusi industry 4.0, perlu dipersiapkan sumber daya yang mempunyai keterampilan handal. Penyiapan sumber daya manusia sangat erat kaitannya dengan kiprah lembaga pendidikan. Penyiapan sumber daya manusia yang unggul dilakukan dengan menentukan perencanaan pembelajaran, membuat program, kurikulum, model dan metode pembelajaran yang dibutuhkan. Dengan demikian, proses pembelajaran harus mengarahkan dan membimbing peserta didik agar memiliki kompetensi yang dibutuhkan. Kompetensi dapat dipahami sebagai sebuah kombinasi antara ketrampilan (skill), atribut personal, dan pengetahuan (knowledge) yang tercermin melalui perilaku kinerja (job behavior) yang dapat diamati, diukur dan dievaluasi. Peserta didik akan memiliki kompetensi yang handal dan unggul, manakala model pembelajaran yang diterapkan mendukungnya. Model pembelajaran yang dibutuhkan untuk menjawab tantangan revolusi industry 4.0, adalah model pembelajaran yang memberikan latihan kepada peserta didik untuk berpikir kritis (critical thinking), kreatif dan inovatif. Model pembelajaran tidak hanya menekankan kepada transfer of knowlage dimana guru sangat dominan dalam proses pembelajaran namun pembelajaran yang menghasilkan peserta didik yang kreatif dan kritis dalam memecahkan permasalahan yang dihadapi. 


\section{Model Pembelajaran Kolaboratif}

Tuntutan revolusi industry 4.0 harus segera direspons oleh lembaga pendidikan dengan mempersiapkan sumber daya yang memiliki kompetensi handal melalui model pembelajaran kolaboratif dan kreatif. Model pembelajaran kolaboratif dimaksudkan untuk melindungi peserta didik dari sikap pasif dan ketergantungan terhadap guru yang memegang otoritas bahan pelajaran. Pembelajaran kolaboratif didefinisikan sebagai kegiatan belajar yang memberi ruang seluasluasnya kepada peserta didik untuk aktif selama proses pembelajaran. Guru lebih berperan dan bertanggung jawab sebagai anggota selama proses mencari pengetahuan oleh peserta didik. Pembelajaran kolaboratif memaksimalkan proses kerjasama yang berlangsung secara alamiah di antara peserta didik. Menciptakan lingkungan pembelajaran yang berpusat pada peserta didik, kontekstual, terintegrasi, dan bersuasana kerjasama. Memberi kesempatan kepada siswa menjadi partisipan aktif dalam proses belajar. Kriteria model pembelajaran kolaboratif diantaranya:

1. Memaksimalkan porses kerja sama peserta didik.

Kerja sama dalam proses pembelajaran dimaksudkan setiap peserta didik akan saling membantu dengan suasana menyenangkan dan tanpa ada rasa minder, menyadari kekurangan dan kelebihan yang dimilikinya serta persaingan yang positif untuk mencapai prestasi belajar yang optimal. Kerja sama peserta didik dapat menumbuhkan karakter positif dan kemampuan atau kompetensi yang sangat dibutuhkan sikap saling mengerti dan percaya satu sama lain, berkomunikasi dengan jelas dan tidak ambigu, saling menerima dan mendukung satu sama lain, belajar bersama akan meningkatkan kemampuan berkomunikasi dan menyelesaikan konflik, belajar bersama akan meningkatkan kemampuan akademik dan sikap positif terhadap sekolah, belajar bersama akan mengurangi aspek negatif kompetisi. (Miftahul Huda, 2011).

2. Pembelajaran berpusat pada peserta didik.

Model pembelajaran berpusat pada siswa (student centered learning) berbeda dari pembelajaran berpusat pada guru (instructor centered learning). Menurut Yeni Rachmawati dan Euis Kurniawati (2010) pembelajaran yang berpusat pada anak, melibatkan anak dalam proses pembelajaran dari awal sampai akhir berupa belajar aktif (active learning), yang lebih menempatkan siswa sebagai pusat dari pembelajaran". Proses pembelajaran menggunakan SCA (student centered approach), inisiatif anak merupakan penentu keberlangsungan proses pembelajaran. Peserta didik melakukan eksplorasi dengan minat lingkungan dan tidak dimonopoli guru.

3. Menumbuhkan Keterampilan social. 
Model pembelajaran kolaboratif dapat menumbuhkan keterampilan social peserta didik dalam menghadapi permasalahan kehidupannya. Keterampilan social adalah kemampuan peserta didik untuk menghadapi dan menyesuaikan diri terhadap situasi baru dan tuntutan lingkungan baru secara cepat, tepat dan efektif. Menurut Sjamsuddin dan Maryani (2008), keterampilan sosial adalah suatu kemampuan secara cakap yang tampak dalam tindakan, mampu mencari, memilah dan mengelola informasi, mampu mempelajari hal-hal baru yang dapat memecahkan masalah sehari-hari, mampu memiliki keterampilan berkomunikasi baik lisan maupun tulisan, memahami, menghargai, dan mampu bekerjasama dengan orang lain yang majemuk, mampu mentranformasikan kemampuan akademik dan beradaptasi dengan perkembangan masyarakat. Untuk menghadapi tuntutan revolusi industri 4.0, peserta didik harus memiliki keterampilan sosial agar mampu mempelajari dan memahami hal-hal yang baru dan cepat beradaptasi dengan perkembangan baru yang terjadi di masyarakat. Menurut E. Maryani (2011) keterampilan sosial dapat dikelompokkan atas empat bagian yang saling berkaitan yaitu:

a. Keterampilan dasar berinteraksi: berusaha untuk saling mengenal, ada kontak mata, berbagi informasi atau material;

b. Keterampilan komunikasi: mendengar dan berbicara secara bergiliran, melembutkan suara (tidak membentak), meyakinkan orang untuk dapat mengemukakan pendapat, mendengarkan sampai orang tersebut menyelesaikan pembicaraannya;

c. Keterampilan membangun tim/kelompok: mengakomodasi pendapat orang, bekerjasama, saling menolong, saling memperhatikan;

d. Keterampilan menyelesaikan masalah: mengendalikan diri, empati, memikirkan orang lain, taat terhadap kesepakatan, mencari jalan keluar dengan berdiskusi, respek terhadap pendapat yang berbeda. Keterampilan sosial akan membantu setiap individu dalam mengkomunikasikan informasi yang akan disampaikan, keterampilan sosial akan membantu individu bekerjasama dalam kelompoknya untuk menyelesaikan masalah.

4. Mengembangkan kemampuan berpikir reflektif.

Dewey berpendapat bahwa pendidikan merupakan proses sosial dimana anggota masyarakat yang belum matang (terutama anak-anak) diajak ikut berpartisipasi dalam masyarakat. Tujuan dari pendidikan adalah memberikan kontribusi dalam perkembangan pribadi dan sosial seseorang melalui pengalaman dan pemecahan masalah yang berlangsung secara reflektif. Tiga sumber utama untuk berfikir reflektif, keingintahuan (curiosity), aran (suggestion) atau ide ide peserta didik dan keteraturan (orderlinnes). Peserta didik mengembangkan ide untuk 
memecahkan masalah dengan cara mengumpulkan data yang dibutuhkan. Dalam tahap ini peserta didik memikirkan, menganalisa dan merumuskan penyelesaian masalah dengan mengumpulkan data-data pendukung. Model pembelajaran kolaboratif memberikan kesempatan kepada peserta didik untuk mengenali masalah yang dihadapi serta bagaimana mencari solusi masalah tersebut. Peserta didik dihadapkan kepada permasalahan yang sifatnya kontekstual seperti internet of things, otomaisasi, e money, e commerce dan bagaimana solusinya serta apa yang harus dilakukannya.

Terdapat lima komponen yang berkenaan dengan kemampuan berpikir reflektif, diantaranya adalah:(Dewey dalam Choy, 2015)

a. Recognize or felt difficulty problem, merasakan dan mengidentifikasi masalah. Masalah mungkin dirasakan siswa setelah siswa membaca data pada soal. Kemudian siswa mencari cara untuk mengetahui apa yang sebenarnya terjadi. Pada langkah ini, siswa merasakan adanya permasalahan dan mengidentifikasinya.

b. Location and definition of the problem, membatasi dan merumuskan masalah. Langkah ini menuntun siswa untuk berpikir kritis. Berdasarkan pengalaman pada langkah pertama tersebut, siswa mempunyai masalah khusus yang merangsang pikirannya, dalam langkah ini siswa mencermati permasalahan tersebut dan timbul upaya mempertajam masalah.

c. Suggestion of possible solution, mengajukan beberapa kemungkinan alternatif solusi pemecahan masalah. Pada langkah ini, siswa mengembangkan berbagai kemungkinan dan solusi untuk memecahkan masalah yang telah dibatasi dan dirumuskan tersebut, siswa berusaha untuk mengadakan penyelesaian masalah.

d. Rational elaboration of an idea, mengembangkan ide untuk memecahkan masalah dengan cara mengumpulkan data yang dibutuhkan. Siswa mencari informasi yang diperlukan untuk memecahkan masalah tersebut, dalam langkah ini siswa memikirkan dan merumuskan penyelesaian masalah dengan mengumpulkan data-data pendukung.

e. Test and formation of conclusion, melakukan tes untuk menguji solusi pemecahan masalah dan menggunakannya sebagai bahan pertimbangan membuat kesimpulan. Siswa menguji kemungkinan dengan jalan menerapkannya untuk memecahkan masalah sehingga siswa menemukan sendiri keabsahan temuannya.

5. Melatih kemampuan leadership.

Kegiatan pembelajaran kolaboratif diarahkan untuk menanamkan kebiasaan kebiasaan (habits) kepada peserta didik untuk memahami apa yang dipelajari, sikap ingin melakukan sesuatu, dan keterampilan bagaimana melakukan sesuatu. Pembelajaran kolaboratif 
merupakan suatu model pembelajaran dalam hal ini para peserta didik belajar bersama secara berkelompok dan diarahkan untuk mencapai tujuan secara kolektif. Iklim belajar yang menekankan kepada belajar bersama dapat mengarahkan peserta didik memiliki keterampilan memimpin. Era revolusi industry 4.0 mengharuskan sumber daya manusia yang memiliki keterampilan leadership. Kepemimpinan diartikan sebagai proses untuk memberikan pengarahan dan pengaruh pada kegiatan yang berhubungan dengan tugas kelompok anggotanya. Pemimpin bertanggungjawab untuk membangun komunikasi dan memotivasi diantara anggota timnya agar mereka mau bekerja sama untuk mencapai tujuan yang telah ditetapkan. Model pembelajaran kolaboratif yang menekankan pada pola belajar bekerja sama dan memecahkan masalah bersama dapat memberikan keterampilan kepemimpinan terhadap peserta didik. Tanggung jawab, mandiri, berinisiatif, tekun, ulet, percaya diri, agresif dan punya hasrat untuk unggul merupakan keterampilan yang sangat dibutuhkan untuk menghadapi era revolusi 4.0. Menurut Soebagio A. dalam Mujamil Qomar (2010), melalui pendidikan kita menyiapkan tenaga-tenaga yang berkualitas, tenaga yang siap latih, dan siap pakai untuk memenuhi kebutuhan masyarakat. Oleh sebab itu latihan kepemimpinan terhadap peserta didik sangat dibutuhkan melalui belajar bersama dalam suatu kelompok belajar.

\section{Model Pembelajaran Kreatif}

Untuk Mengahadapi tantangan era revolusi industry 4.0, lembaga pendidikan harus menghasilkan peserta didik yang tidak hanya memiliki kompetensi ketarampilan social namun memiliki kemampuan berfikir kreatif. Keterampilan social dihasilkan melalui model pembelajaran kolaboratif dan kreatifitas peserta didik untuk memecahkan masalah adalah produk dari model pembelajaran kreatif.

Menurut Wena (2013) kreativitas terkait langsung dengan produktivitas dan merupakan bagian esensial dalam pemecahan masalah. Kreativitas dan produktivitas merupakan hal hal yang saling berkaitan dalam proses pembelajaran. Kreatifitas peserta didik harus ditumbuhkan dan harus menjadi sikapnya untuk menjawab tantangan era revolusi industry 4.0. Kreativitas merupakan hal yang sangat penting untuk dikembangkan dalam proses pembelajaran. Kreativitas diperlukan dalam berbagai segi kehidupan, dalam kehidupan bermasyarakat, dunia kerja, perkembangan ilmu pengetahuan dan teknolog.

Menurut Zulkifli dalam Sulihawati (2011) model pembelajaran kreatif merangsang siswa untuk lancar dan luwes dalam berfikir, mampu melihat suatu masalah dari berbagai sudut pandang dan mampu melahirkan banyak gagasan yang sangat menarik selama pembelajaran yang 
disertai usaha-usaha yang dapat menciptakan suasana yang bermakna. Konteks pembelajaran kreatif dapat ditumbuhkan dengan menciptakan suasana kelas yang memungkinkan siswa dan guru merasa bebas mengkaji dan mengeksplorasi topik - topik penting kurikulum dan menganalisa persoalan-persoalan yang terkait dengan kehidupan nyata. Peserta didik diharapkan memiliki kemampuan dalam melihat masalah, memiliki kemampuan menciptakan ide atau gagasan untuk memecahkan masalah. Mohammad Asrori (2012), memaparkan bahwa kreativitas adalah ciri-ciri khas yang dimiliki oleh individu yang ditandai dengan adanya kemampuan untuk menciptakan sesuatu dari kombinasi karya-karya yang telah ada sebelumnya, menjadi suatu karya baru yang berbeda dengan apa yang telah ada sebelumnya dan dilakukan melalui interaksi dengan lingkungannya. Kemampuan berfikir kreatif sangat dibutuhkan untuk menghadapi permasalahan, dan mencari alternatif pemecahannya dengan cara berpikir divergen. Dengan demikian kreativitas sering digambarkan dengan kemampuan berpikir kritis, mempunyai banyak ide, mampu menggabungkan sesuatu gagasan yang belum pernah tergabung sebelumnya dan kemampuan untuk menemukan ide untuk memecahkan permasalahan. Kreativitas merupakan komponen penting dalam pembelajaran untuk menjawab tantangan era revolusi industry 4.0.

Kemampuan berpikir kreatif dari peserta didik harus menjadi tujuan dari pembelajaran dan hal itu dapat dihasilkan melalui model pembelajaran kreatif. Menurut Liliawati dan Puspita (2010) mengatakan bahwa : Keterampilan berpikir kreatif adalah keterampilan kognitif untuk memunculkan dan mengembangkan gagasan baru, ide baru sebagai pengembangan dari ide yang telah lahir sebelumnya dan keterampilan untuk memecahkan masalah secara divergen (dari berbagai sudut pandang). Kemampuan berpikir kreatif dapat diukur dengan memberikan tes pada beberapa aspek yaitu berpikir lancar, berpikir luwes, orisinalitas berpikir dan penguraian serta berfikir utuh. Guilford dalam Munandar (2012).

1. Kelancaran berfikir (fluency of thinking).

Kemampuan berfikir untuk menghasilkan banyak ide yang keluar dari pemikiran seseorang secara cepat. Peserta didik diharapkan memiliki banyak ide dan gagasan sehubungan dengan topik yang sedang didiskusikan dalam pembelajaran berlangsung. Hal ini akan merangsang peserta didik untuk terbiasa berfikir dalam menghadapi persoalan kehidupan di masyarakat sekaligus memberikan solusinya. Peserta didik dapat menjawab dengan sejumlah jawaban jika ada pertanyaan atau mengemukakan ide yang sifatnya solutif terhadap suatu permasalahan. Lancar dalam mengungkapkan gagasan-gagasannya dan merespon dengan cepat terhadap kesalahan dan kelemahan dari suatu objek atau situasi sehingga berupaya untuk menyempurnakannya. 
2. Keluwesan berpikir (flexibility of thinking).

Kemampuan berfikir untuk memproduksi sejumlah ide, jawaban-jawaban atau pertanyaanpertanyaan yang bervariasi. Keluwesan berfikir dapat melihat suatu masalah dari sudut pandang yang berbeda-beda, mencari alternatif atau arah yang berbeda-beda, serta mampu menggunakan bermacam-macam pendekatan atau pemikiran. Peserta didik dapat memiliki kemampuan untuk memberikan bermacam-macam penafsiran terhadap suatu gambar, cerita, atau masalah. Peserta didik terbiasa membangun keluwesan berfikir yakni, jika diberi suatu masalah biasanya memikirkan bermacam-macam gagasan untuk menyelesaikannya. Peserta didik dapat menggolongkan hal-hal menurut pembagian (kategori) yang berbeda sebagai bukti dari keluwesan berfikirnya. Keluwesan berfikir merupakan hal yang sangat penting untuk menghadapi tantangan era revolusi industry 4.0. Peserta didik dengan keluwesan berfikirnya dapat menemukan gagasan baru yang dibutuhkan oleh masyarakat.

3. Elaborasi berfikir (Elaboration of thinking).

Kemampuan berfikir dalam mengembangkan gagasan dan menambahkan atau memperinci suatu objek, gagasan atau situasi. Dengan kemampuan elaborasi berfikir, peserta didik dapat mencari arti yang lebih mendalam terhadap jawaban atau pemecahan masalah dengan melakukan langkah langkah yang terperinci. Daya berfikirnya mampu mengembangkan atau memperkaya gagasan orang lain sehingga ide yang sudah ada dikembangkan menjadi lebih tepat guna sesuai kebutuhan.

4. Keaslian berfikir (originality of thinking)

Kemampuan berfikir untuk membaca, mengamati dan menganalisa ide dan temuan yang sudah ada sehingga dikembangkan menjadi suatu ide yang baru. Peserta didik memiliki kemampuan berpikir kreatif untuk melahirkan sesuatu yang baru, baik berupa gagasan maupun karya nyata yang relatif berbeda dengan yang telah ada sebelumnya. Keaslian berfikir inilah yang diharapkan muncul dari setiap peserta didik sehingga akan lahir sumber daya manusia yang handal. Peserta didik yang dapat menghadapi tantangan era revolusi industry 4.0, juga menciptakan peradaban baru sebagai manifestasi dari kemampuan berfikir kreatifnya.

\section{Keutuhan berfikir (integration of think)}

Integralisme merupkan wawasan kemenyeluruhan dalam memandang segala sesuatu, baik agama, sains, teknologi, dan seni. Integralisme melihat semua itu sebagai satu kesatupaduan yang tak bisa dipecah ataupun dipisahkan dari kesepaduan realitas.(hartono: 2014) Berfikir utuh atau integrative of think harus dikembangkan di sekolah agar peserta didik memiliki 
kemampuan berfikir yang sifatnya menyeluruh dalam menghadapi fenomena kekinian. Kemampuan berfikir integrative dapat dilihat dari ketrampilan peserta didik menginterpretasi, menganalisis, mengevaluasi, dan menyimpulkan, menjelaskan apa yang dipikirkannya dan membuat keputusan. Peserta didik tidak hanya mengetahu masalah namun memahami penyebab munculnya masalah, melokalisir masalah, mengkoding masalah, menginventaris dan mengklasifikasi masalah serta solusi yang tepat dari permasalan itu berikut dampaknya. Dengan demikian, kemampuan berfikir menyeluruh (integratif) harus disiapkan dan dorong oleh guru dalam setiap proses pembelajaran agar peserta didik memiliki kompetensi yang handal dalam menghadapi tantangan revolusi industri 4.0.

\section{KESIMPULAN}

Tuntutan revolusi idustri 4.0 harus segera direspons oleh lembaga pendidikan dengan mempersiapkan sumber daya yang memiliki kompetensi handal. Melalui model pembelajaran kolaboratif dan kreatif peserta didik diharapkan dapat memiliki kemampuan keterampilan social dan kemampuan berfikir kreatif. Model pembelajaran kolaboratif menekankan terhadap penciptaan lingkungan pembelajaran yang berpusat pada peserta didik, kontekstual, terintegrasi, dan bersuasana kerjasama. Pembelajaran kolaboratif memberi kesempatan kepada siswa menjadi partisipan aktif dalam proses belajar. Model pembelajaran kolaboratif akan menghasilkan peserta didik yang memiliki keterampilan sosial.

Model pembelajaran kreatif dapat menciptakan dan menumbuhkan peserta didik yang memiliki kemampuan berfikir dalam berbagai hal untuk mencari solusi yang tepat dalam menghadapi era revolusi industry 4.0. Peserta didik dengan kemampuan berfikirnya dapat menemukan gagasn, ide baru dan mampu mengaplikasikan ide tersebut yang dibutuhkan oleh masyarakat. Dengan demikian, peserta didik yang memiliki kemampuan berfikir dan keterampilan social yang handal dapat menjawab sekaligus solusi yang sangat tepat untuk menghadapi tantangan era revolusi industry 4.0 .

\section{ACKNOWLEDGEMENT}

Ucapan terima kasih dan penghargaan diberikan kepada berbagai pihak yang telah berkontribusi untuk selesainya penelitian ini. Terutama kepada dosen pembimbing Mata Kuliah Manajemen Pendidikan Islam UIN Sunan Gunung Djati Bandung dan seluruh teman program 
doctoral yang senantiasa memberikan masukan untuk kelengkapan dan kesempurnaan terhadap penelitian ini agar dijadikan sebuah tulisan dalam bentuk jurnal. Terima kasih juga saya sampaikan kepada tim editor SCAFFOLDING (Jurnal Pendidikan Islam dan Multikulturalisme) IAIN Sunan Giri Ponorogo yang telah memberikan kesempatan terhadap peneliti untuk berkarya dan untuk diterbitkan dalam jurnal SCAFFOLDING

\section{BIBLIOGRAFI}

Banu Prasetyo dan Umi Trisyanti, (2018). Strategi Pembangunan Nasional Menghadapi Revolusi Industri 4.0". UPT PMK Sosial Humaniora. FBMT. Institut Teknologi Sepuluh Nopember Prosiding SEMATEKSOS 3.

Balasingham, K. (2016). Industry 4.0: Securing the Future for German Manufacturing Companies. Master's Thesis. University of Twente.

Bonekamp, L., \& Sure, M. (2015). Consequences of Industry 4.0 on human labour and work organisation. J. Bus. Media Psychol, No.6, pp.33-40.

Beetlestone, Florence. (2013). Creative Learning; Strategi Pembelajaran Untuk Melesatkan Kreativitas Siswa. Nusa Media.

Burnham, J. F. (2006). Scopus database: a review. Biomedical digital libraries, 3(1), p.1. Davies, R. (2015). Industry 4.0 Digitalisation for productivity and growth. http://www.europarl.europa.eu/RegData/etudes/BRI E/2015/568337/EPRS BRI(20

Choy, (2015). Pemikiran Reflektif oleh Dewey, diakses dari http://www.teachersrock.net/Dewey\%20Pemikiran\%20Refleksi.htm (25 januari 2015

Eveline Siregar \& Hatini Nara. (2011). Teori Belajar dan Pembelajaran. Galia Indonesia

E. Maryani, (2011), Pengembangan Program Pembelajaran IPS Untuk Peningkatan Keterampilan Sosial. Bandung: Alfabeta.

Genarsih, T., Kusmayadi, T. A., \& Mardiyana. (2015). Proses Berpikir Reflektif Siswa Sma Dalam Pemecahan Masalah Pada Materi Turunan Fungsi Ditinjau Dari Efikasi Diri. Jurnal Elektronik Pembelajaran Matematika Issn: 2339-1685, Vol.3, No.7, Hal 787-795.

Hartono, (2014 ). KERANGKA BERPIKIR PEMBELAJARAN INTEGRATIF, jurnal Insania, Vol. 19, No. 2, Juli - Desember 2014.

Hepsi Nindiasari, dkk (2017), ANALISIS KEMAMPUAN BERPIKIR REFLEKTIF MATEMATIS SISWA DITINJAU DARI GAYA BELAJAR, Prima: Jurnal Pendidikan Matematika Vol. 1, No. 1, Juli 2017, hal. 69-82P-ISSN: 2579-9827, E-ISSN: 2580-221

Heng, S. (2014). Industry 4.0: Upgrading of Germany's Industrial Capabilities on the Horizon. https://ssrn.com/abstract=2656608.

Hoedi Prasetyo dan Wahyudi Sutopo., (2018). INDUSTRI 4.0: TELAAH KLASIFIKASI ASPEK DAN ARAH PERKEMBANGAN RISET. RISET." J@ti Undip : Jurnal Teknik Industri. vol. 13, no. 1, pp. 17-26, Mar. 2018.

Isjoni. (2013). Cooperative learning: Mengembangkan Kemampuan Belajar Berkelompok. Bandung: Alfabeta.

Kagermann, H., Lukas, W.D., \& Wahlster, W. (2013). Final report: Recommendations for implementing the strategic initiative INDUSTRIE 4.0. Industrie 4.0 Working Group

Liliawati dan Puspita. (2010). Evektivitas Pembelajaran Berbasis Masalah dalam Meningkatkan Keterampilan Berpikir Kreatif Siswa. Prosiding Seminar Nasional Fisika 2010. Universitas Pendidikan Indonesia . Bandung

Miftahul Huda, (2011), Cooperative Learning, Jakarta : Pustaka Pelajar. 
Munandar, (2012). Pengembangan kreativitas anak berbakat. Cetakan ke-3. Jakarta : Rineka cipta Mohammad Asrori. (2012). Psikologi Remaja Perkembangan Peserta Didik. Jakarta: PT. Bumi Aksara.

Qiqi Yuliati Zakiah, (2019). Kapita Selekta Ilmu Pendidikan. Bandung: Mimbar Pustaka.

Ritzer, G. (2010). Globalization: A Basic Text. English: Wiley-Blakwell.

Sandu, C. (2012). Globalization: Definition, Processes and Concepts. Journal Of Natıonal Instıtute Of Statistics.

Sjamsuddin dan Maryani E. (2008). Pengembangan Program Pembelajaran IPS untuk Meningkatkan Kompetensi Keterampilan Sosial. Makasar: Makalah pada Seminar Nasional.

Shwab, K. (2016). The Fourth Industrial Revolution. New York: Crown Business.

Suwarno, W. (2009). Dasar-dasar Ilmu Pendidikan. Yogyakarta: Ar-Ruzz Media.

Safrida, L. N., Susanto, \& Kurniati, D. (2015). Analisis Proses Berpikir Siswa Dalam Pemecahan Masalah Terbuka Berbasis Polya Sub Pokok Bahasan Tabung Kelas IX SMP Negeri 7 Jember. Jurnal Edukasi Universitas Jember.

Sulihawati, Siswantoro, Sowiyah. (2013). PENINGKATAN AKTIVITAS DAN HASIL BELAJAR MELALUI MODEL PEMBELAJARAN KREATIF PRODUKTIF. jurnal.fkip.unila, Vol. 1, N0. 8, 2013.

Yeni Rachmawati \& Euis Kurniawati. (2010). Strategi Pengembangan Kreativitas pada Anak: Usia Taman Kanak-Kanak. Jakarta: Kencana Prenada Media Group.

Zubaedi, (2011). Desain Pendidikan Karakter Konsepsi dan Aplikasinya dalam Lembaga Pendidikan. Jakarta: Kencana.

Wena, M, (2013). Strategi Pembelajaran Inovatif Kontemporer: Suatu Tinjauan Konseptual Operasional. Jakarta: PT. Bumi Aksara. 